\title{
THE EFFECT OF CURRENT RATIO (CR), DEBT TO EQUITY RATIO (DER), TOTAL ASSET TURNOVER (TAT) AND FIRMS SIZE (FS) TO RETURN ON EQUITY (ROE) IN MINING COMPANIES LISTED ON THE INDONESIA STOCK EXCHANGE IN 2013 -2018.
}

\author{
Mahmudin', Elfreda Aplonia Lau', Beatrix Tandirerung ${ }^{3}$ \\ University of 17 Agustus 1945 Samarinda \\ Jl.Ir. Juanda No 80, 75124 Indonesia \\ 1elfredalau9@gmail.com
}

\begin{abstract}
This research was conducted to know and analysis the effect of Current Ratio $(C R)$, Debt to Equity Ratio (DER), Total Asset Turnover (TAT) and Firm Size (FS) on Return on Equity (ROE) in mining companies listed on the Indonesia Stock Exchange in 2013 -2018. The study was conducted using multiple linear regression methods.

The results of research say that simultaneously Current Ratio (CR), Debt to Equity Ratio (DER), Total Asset Turnover (TAT) and Firm Size (FS) have a significant effect on Return on Equity (ROE. The test results show that Partially Debt to Equity Ratio (DER) and Firm Size (FS) have a positive and significant effect on Return on Equity (ROE). While Total Asset Turnover (TAT) has a positive and significant effect on Return on Equity (ROE). On the other hypothesis testing, Current Ratio (CR) has no significant effect on Return on Equity (ROE).
\end{abstract}

Keywords : Current Ratio (CR), Debt to Equity Ratio (DER), Total Asset Turnover (TAT), Firm Size (FS), Return on Equity (ROE)

\section{PENDAHULUAN}

Penelitian ini bertujuan untuk mengetahui dan menganalisis: pengaruh secara parsial maupun secara simultan dari Current Ratio, Debt to Equity Ratio, Total Asset Turnover dan Firm Size terhadap Return on Equity perusahaan mining yang terdaftar di BEI pada tahun 2013-2018. Hal yang mendasari penelitian ini adalah pertimbangan bahwa faktor-faktor tersebut merupakan merupakan factor yang berpengaruh terhadap Return on Equity karena menurut Sawir(2009:10) Current ratio merupakan perbandingan antara aktiva lancar dan kewajiban lancar dan merupakan ukuran yang paling umum digunakan untuk mengetahui kesanggupan suatu perusahaan memenuhi kewajiban lancarnya. Demikian pula Debt to Equity Ratio menggambarkan sampai sejauh mana modal pemilik dapat menutupi hutang-hutang kepada pihak luar dan merupakan rasio yang mengukur hingga sejauh mana perusahaan dibiayai 
dari hutang sebagaimana yang dinyatakan oleh Hery (2016: 168).

Selanjutnya Kasmir (2013: 185) berpendapat bahwa Total asset turnover merupakan rasio yang digunakan untuk mengukur perputaran semua aktiva yang dimiliki perusahaan dan mengukur berapa jumlah penjualan yang diperoleh dari setiap rupiah yang dihasilkan.Lebih lanjut Brigham dan Houston (2010: 4) berpendapat bahwa ukuran perusahaan merupakan ukuran besar kecilnya sebuah perusahaan yang ditunjukan atau dinilai oleh total asset, total penjualan, jumlah laba, beban pajak dan lain-lain.

Perusahaan yang dipilih dalam penelitian ini adalah perusahaan yang sahamnya terdaftar di BEI periode 20132018 yang termasuk dalam kelompok perusahaan pertambangan. Pemerintah mengakui eksistansi perusahaan go public dengan dikeluarkanya Surat Keputusan Menteri Keuangan No KEP640/MK/IV/5/1974 tanggal 6 Mei 1974 tentang pengaturan penawaran efek.

Pemilihan industri ini didasarkan pada pertimbangan dunia pertambangan Indonesia yang memiliki profil yang sangat luar biasa. Menurut Survei Geologi Amerika Serikat (USGS) Indonesia menduduki peringkat keenam sebagai negara yang kaya akan sumber daya tambang. Selain itu, dari potensi bahan galiannya untuk batubara, Indonesia menduduki peringkat ketiga untuk ekspor batubara, peringkat kedua untuk produksi timah, peringkat kedua untuk produksi tembaga, dan peringkat keenam untuk produksi emas (Fahruddin, 2018: 2). Hal ini membuat industri pertambangan berkembang di Indonesia, sehingga para pelaku bisnis seperti investor, manajemen, kreditur atau pihak berkepentingan di tuntut untuk lebih selektif dan cermat dalam pengambilan keputusan investasi.

Berdasarkan paparan tersebut, maka dirumuskan pertanyaan penelitian berikut ini:

1. Apakah Current Ratio berpengaruh signifikan terhadap Return on Equity perusahaan mining yang terdaftar di BEI pada tahun 2013-2018?

2. Apakah Debt to Equity Ratio berpengaruh signifikan terhadap Return on Equity perusahaan mining yang terdaftar di BEI pada tahun 20132018 ?

3. Apakah Total Asset Turnover berpengaruh signifikan terhadap Return on Equity pada perusahaan mining yang terdaftar di BEI pada tahun 2013-2018?

4. Apakah Firm Size berpengaruh signifikan terhadap Return on Equity 
pada perusahaan mining yang terdaftar di BEI tahun pada 2013-2018?

5. Apakah Current Ratio, Debt to Equity Ratio, Total Asset Turnover dan Firm Size secara simultan berpengaruh signifikan terhadap Return on Equity pada perusahaan mining yang terdaftar di BEI pada tahun 2013-2018?

\section{KERANGKA TEORITIS}

Teori yang mendasari penelitian ini adalah profitabilitas dan struktur modal, yang dipaparkan beriku ini.

\section{Profitabilitas}

Profitabilitas disebut juga sebagai rentabilitas sebagaimana yang disampaikan oleh Harahap (2009: 304) bahwa: rasio rentabilitas atau disebut juga profitabilitas menggambarkan kemampuan perusahaan mendapatkan laba melalui semua kemampuan, dan sumber yang ada seperti kegiatan penjualan, kas, modal, jumlah karyawan, jumlah cabang, dan sebagainya. Rasio yang menggambarkan kemampuan perusahaan menghasilkan laba disebut juga operating ratio.

Selanjutnya Kasmir (2013: 199207): berpendapat bahwa Profitabilitas dapat diukur dari: 1) Profit Margin on Sales atau rasio profit margin atau margin laba atas penjualan. 2) Return on
Investment (ROI) yaitu rasio yang menunjukkan hasil (return) atas jumlah aktiva yang digunakan dalam perusahaan. 3) Return on Equity (ROE) merupakan rasio untuk mengukur laba bersih sesudah pajak dengan modal sendiri. 4) Laba per lembar saham atau disebut juga rasio nilai buku

Pada penelitian ini profitabilitas dicerminkan dari Return on Equity (ROE) yaitu rasio yang digunakan untuk mengukur laba bersih sesudah pajak dengan modal sendiri. Rasio ini menunjukkan efisiensi penggunaan modal sendiri. Semakin tinggi rasio ini, semakin baik. Artinya posisi pemilik perusahaan semakin kuat, demikian pula sebaliknya

\section{Struktur Modal}

Menurut Kasmir (2013: 151) "rasio solvabilitas atau leverage ratio merupakan rasio yang digunakan untuk mengukur sejauh mana aktiva perusahaan dibiayai dengan utang".

Menurut Harahap (2009: 303), rasio solvabilitas atau struktur modal adalah:

Menurut Hanafi dan Halim (2012: 79) rasio solvabilitas adalah: Rasio yang mengukur kemampuan perusahaan memenuhi kewajiban- kewajiban jangka panjangnya. Perusahaan yang tidak solvabel adalah perusahaan yang total 
utangnya lebih besar dibandingkan total asetnya. Rasio ini mengukur likuiditas jangka panjang perusahaan dan dengan demikian memfokuskan pada sisi kanan neraca.

Terdapat beberapa macam rasio yang dapat dihitung, antara lain yang diketengahkan oleh Kasmir (2013: 156):

1) Debt to Assets Ratio

Debt to Asset Ratio (DAR) merupakan rasio utang yang digunakan untuk mengukur perbandingan antara total utang dengan total aktiva. Dengan kata lain, seberapa besar aktiva perusahaan dibiayai oleh hutang atau seberapa besar utang perusahaan berpengaruh terhadap pengelolaan aktiva.

2) Long Term Debt to Equity Ratio (LTDtER)

Long Term Debt to Equity Ratio (LTDtER) merupakan rasio antara utang jangka panjang dengan modal sendiri. Tujuannya adalah untuk mengukur berapa bagian dari setiap rupiah modal sendiri yang dijadikan jaminan utang jangka panjang dengan cara membandingkan antara utang jangka panjang dengan modal sendiri yang disediakan oleh perusahaan.

3) Times Interest Earned

Times Interest Earned (TIE) merupakan rasio untuk mengukur sejauh mana pendapatan dapat menurun tanpa membuat perusahaan merasa malu karena tidak mampu membayar biaya bunga tahunannya.

4) Debt to Equity Ratio (DER)

Debt to equity ratio merupakan rasio yang digunakan untuk menilai utang dengan ekuitas. Rasio ini dicari dengan cara membandingkan antara seluruh utang, termasuk utang lancar dengan seluruh ekuitas. Rasio ini berguna untuk mengetahui jumlah dana yang disediakan peminjam (kreditor) dengan pemilik perusahaan.

5) Fixed Charge Coverage (FCC)

Fixed Charge Coverage atau lingkup biaya tetap merupakan rasio yang menyerupai Times Interest Earned Ratio. Hanya saja perbedaannya adalah rasio ini dilakukan apabila perusahaan memperoleh utang jangka panjang atau menyewa aktiva berdasarkan kontrak sewa. Biaya tetap merupakan biaya bunga ditambah 
kewajiban sewa tahunan atau jangka panjang.

\section{Rasio Aktivitas}

Menurut Kasmir (2013: 172) rasio aktivitas (activity ratio) merupakan rasio yang digunakan untuk mengukur efektivitas perusahaan dalam menggunakan aktiva yang dimilikinya.

Menurut Hanafi (2009: 76), rasio aktivitas adalah:

Rasio yang melihat pada beberapa aset kemudian menentukan beberapa tingkat aktivitas aktiva-aktiva tersebut pada tingkat kegiatan tertentu. Aktivitas yang rendah pada tingkat penjualan tertentu akan mengakibatkan semakin besrnya dana kelebihan yang tertanam pada aktiva-aktiva tersebut.

Menurut Harahap (2009: 308) rasio aktivitas, rasio ini menggambarkan aktivitas yang dilakukan perusahaan dalam menjalankan operasinya baik dalam kegiatan penjualan, pembelian dan kegiatan lainnya. Terdapat beberapa macam rasio yang dapat dihitung (Kasmir, 2013: 176), antara lain:

\section{1) Total Assets Turnover}

Total Asset Turnover merupakan rasio yang digunakan untuk mengukur perputaran semua aktiva yang dimiliki perusahaan dan mengukur berapa jumlah penjualan yang diperoleh dari tiap rupiah aktiva.

\section{2) Receivable Turnover}

Perputaran piutang (Receivable Turnover) merupakan rasio yang digunakan untuk mengukur berapa lama penagihan piutang selama satu periode atau berapa kali dana yang ditanam dalam piutang ini berputar dalam satu periode.

\section{3) Inventory Turnover}

Perputaran Sediaan merupakan rasio yang digunakan untuk mengukur berapa kali dana yang ditanam dalam sediaan (inventory) ini berputar dalam suatu periode. Rasio ini dikenal dengan nama rasio perputaran sediaan (inventory turnover). Dapat diartikan pula bahwa perputaran sediaan merupakan rasio yang menunjukkan berapa kali jumlah barang sediaan diganti dalam satu tahun. Semakin kecil rasio ini, semakin jelek demikian pula sebaliknya.

4) Working Capital Turnover

Perputaran modal kerja atau working capital turnover merupakan salah satu rasio untuk mengukur atau menilai keefektifan modal kerja perusahaan selama periode tertentu. Artinya seberapa banyak modal kerja berputar selama suatu periode atau dalam suatu periode.

5) Fixed Assets Turnover 
Fixed Assets Turnover merupakan rasio yang digunakan untuk mengukur berapa kali dana yang ditanamkan dalam aktiva tetap berputar dalam satu periode. Atau dengan kata lain, untuk mengukur apakah perusahaan sudah menggunakan kapasitas aktiva tetap sepenuhnya atau belum.

\section{Return on Equity}

Menurut Kasmir (2013: 204) "Return on Equity (ROE) merupakan rasio untuk mengukur laba bersih sesudah pajak dengan modal sendiri. Rasio ini menunjukkan efisiensi penggunaan modal sendiri. Semakin tinggi rasio ini, semakin baik.Artinya posisi pemilik perusahaan semakin kuat, demikian pula sebaliknya".

Menurut Hanafi dan Halim (2012: 82) "Return on Equity (ROE), rasio ini mengukur kemampuan perusahaan menghasilkan laba berdasarkan modal saham tertentu". Rasio ini merupakan ukuran profitabiitas dari sudut pandang pemegang saham.

Dari pengertian diatas variabel yang digunakan untuk mewakili profitabilitas adalah Return on Equity (ROE). Return on Equity (ROE) memberikan indikasi mengenai seberapa baik sebuah perusahaan untuk menghasilkan keuntungan.
Semakin besar nilai ROE, menunjukkan kinerja perusahaan yang semakin baik pula, karena tingkat pengembalian investasi semakin besar dimana rasio ini memperlihatkan sejauh manakah perusahaan mengelola modal sendiri (net worth) secara efektif, mengukur tingkat keuntungan dari investasi yang telah dilakukan pemilik modal sendiri atau pemegang saham perusahaan (Sawir 2009: 20).

\section{Current Ratio}

Munawir

(2010:

mendefinisikan Current Ratio sebagai perbandingan antara jumlah aktiva lancar dengan hutang lancar. Ratio ini menunjukkan bahwa nilai kekayaan lancar (yang segera dapat dijadikan uang) ada sekian kalinya hutang jangka pendek".

\section{Total Asset Turnover}

Total asset turnover (TAT) menunjukan bagaimana afektifitas perusahaan menggunakan keseluruhan aktiva untuk meningkatkan nilai penjualan dan meningkatkan laba. Rasio total asset turnover menunjukkan perputaran total aktiva diukur dari volume penjualan dengan kata lain seberapa jauh kemampuan semua aktiva menciptakan penjualan (Harahap, 2009: 309).

TAT dipengaruhi oleh nilai penjualan bersih yang dilakukan oleh 
perusahaan dibandingkan dengan nilai aktiva total yang dimiliki oleh perusahaan. Bila nilai TAT ditingkatkan berarti terjadi kenaikan penjualan bersih perusahaan, peningkatan penjualan bersih perusahaan akan mendorong peningkatan laba sehingga mempengaruhi profitabilitas perusahaan. Rasio TAT yang tinggi biasanya menunjukkan manajemen yang baik, sebaliknya rasio yang rendah harus memebuat manajemen mengevaluasi strategi, pemasarannya, dan pengeluaran modalnya.

\section{Firm Size}

Menurut Brigham dan Houston (2010: 4) "ukuran perusahaan merupakan ukuran besar kecilnya sebuah perusahaan yang ditunjukan atau dinilai oleh total asset, total penjualan, jumlah laba, beban pajak dan lain-lain".

\section{Debt to Equity Ratio}

Menurut Kasmir (2013: 157) "debt to equity ratio merupakan rasio yang digunakan untuk menilai utang dengan ekuitas". Rasio ini dicari dengan cara membandingkan antara seluruh utang, termasuk utang lancar dengan seluruh ekuitas. Rasio ini berguna untuk mengetahui jumlah dana yang disediakan peminjam (kreditor) dengan pemilik perusahaan.

Bagi kreditor, semakin besar rasio ini, akan semakin tidak menguntungkan karena akan semakin besar risiko yang ditanggung atas kegagalan yang mungkin terjadi di perusahaan. Namun, bagi perusahaan justru semakin besar rasio akan semakin baik. Sebaliknya dengan rasio yang rendah, semakin tinggi tingkat pendanaan yang disediakan pemilik dan semakin besar batas pengamanan bagi peminjam jika terjadi kerugian atau penyusutan terhadap nilai aktiva.

Dari definisi tersebut variabel yang digunakan untuk mewakili struktur modal adalah Debt to Equity Ratio (DER). Salah satu rasio yang diperhatikan oleh investor adalah Debt to Equity Ratio (DER), karena dapat menunjukkan komposisi pendanaan dalam membiayai aktivitas operasional perusahaan atau memanfaatkan utang-utangnya. Utang merupakan salah satu aspek yang menjadi dasar penilaian bagi investor untuk mengukur kondisi keuangan.

\section{Hipotesis Penelitian}

Berdasarkan rumusan masalah, dasar teori dan kerangka konsep, maka hipotesis penelitian ini dirumuskan sebagai berikut:

1. Current Ratio berpengaruh signifikan terhadap Return on Equity pada perusahaan mining yang terdaftar di BEI tahun 2013-2018. 
2. Debt to Equity Ratio berpengaruh signifikan terhadap Return on Equity pada perusahaan mining yang terdaftar di BEI tahun 2013-2018.

3. Total Asset Turnover berpengaruh signifikan terhadap Return on Equity pada perusahaan mining yang terdaftar di BEI tahun 2013-2018.

4. Firm Size berpengaruh signifikan terhadap Return on Equity pada perusahaan mining yang terdaftar di BEI tahun 2013-2018.

5. Current Ratio, Debt to Equity Ratio, Total Asset Turnover dan Firm Size secara simultan berpengaruh signifikan terhadap Return on Equity pada perusahaan mining yang terdaftar di BEI tahun 2013-2018.

\section{METODE PENELITIAN}

\section{Operasionalisasi variabel}

Variabel dan indikator variabel penelitian ini meliputi variabel dependen dan variabel independen yang diuraikan berikut ini:

1) Return on Equity (Y) sebagai variabel dependen

Adalah rasio untuk mengukur laba bersih sesudah pajak dengan modal sendiri pada Perusahaan Mining yang Terdaftar di BEI Tahun 2013-2018.

2) Current Ratio $\left(\mathrm{X}_{1}\right)$
Adalah rasio yang digunakan untuk mengukur sejauh mana aktiva lancer dapat digunakan untuk menutupi kewajiban jangka pendek atau hutang lancar pada Perusahaan Mining yang Terdaftar di BEI Tahun 2013-2018.

3) Debt to Equity Ratio $\left(\mathrm{X}_{2}\right)$

Merupakan rasio yang digunakan untuk menilai utang dengan ekuitas. Rasio ini dicari dengan cara membandingkan antara seluruh utang, termasuk utang lancar dengan seluruh ekuitas pada Perusahaan Mining yang Terdaftar di BEI Tahun 2013-2018.

4) Total Asset Turnover $\left(\mathrm{X}_{3}\right)$

Adalah rasio yang digunakan untuk mengukur sejauh mana kemampuan perusahaan menghasilkan penjualan berdasarkan total aktiva yang pada Perusahaan Mining yang Terdaftar di BEI Tahun 2013-2018.

5) Firm Size $\left(\mathrm{X}_{4}\right)$

Ukuran perusahaan merupakan ukuran besar kecilnya perusahaan yang dinilai dari total asset, total penjualan, jumlah laba, beban pajak dan lain-lain pada perusahaan Mining yang Terdaftar di BEI Tahun 20132018.

\section{Teknik Pengumpulan Data}

Data yang digunakan dalam penelitian ini dihimpun dengan penelitian kepustakaan (Library Reserch) yaitu 
pengumpulan data laporan yang diperoleh dari Idn Financial

\section{Populasi dan Sampel Penelitian}

Populasi dalam penelitian ini adalah semua perusahaan mining yang terdaftar di BEI tahun 2013-2018 sebanyak 43 perusahaan. Perusahaan mining yang dijadikan sampel dalam penelitian ini adalah perusahaan mining yang terdaftar selama periode penelitian dan mempublikasikan Laporan Keuangan secara lengkap selama periode penelitian, maka perusahaan yang dijadikan sampel penelitian sebanyak 25 perusahaan

\section{Teknik Analisis}

Analisis data dalam penelitian ini adalah menggunakan bantuan alat statistic yaitu program SPSS. Teknik analisis data yang digunakan dalam penelitian ini adalah analisis regresi linier berganda sebagai berikut: $\mathrm{Y}=\mathrm{a}+\mathrm{b}_{1} \mathrm{X}_{1}-\mathrm{b}_{2} \mathrm{X}_{2}+$ $\mathrm{b}_{3} \mathrm{X}_{3}+\mathrm{b}_{4} \mathrm{X}_{4}+\mathrm{e}$, dimana $\mathrm{Y}=$ Return on Equity (ROE), $\mathrm{a}=$ Konstanta, $\mathrm{b}=$ Koefisien regresi, $\mathrm{X}_{1}=$ Current Ratio (CR), $\mathrm{X}_{2}=$ Debt to Equity Ratio (DER), $\mathrm{X}_{3}=$ Total Asset Turnover (TAT) dan $\mathrm{X}_{4}=$ Firm Size $(\mathrm{FS})$

Variabel dalam penelitian ini diukur menggunakan rasio-rasio keuangan pada ta bel berikut:

Tabel 1. Teknik Pengukuran Variabel

\begin{tabular}{|c|c|}
\hline Variabel & Formulasi \\
\hline $\begin{array}{l}\text { Return } \\
\text { on } \\
\text { Equity }\end{array}$ & $\begin{array}{l}\text { ROE } \\
=\frac{\text { Laba Bersih }}{\text { Ekuitas }} \text { X 100\% }\end{array}$ \\
\hline $\begin{array}{l}\text { Debt to } \\
\text { Equity } \\
\text { Ratio }\end{array}$ & $\begin{array}{l}\text { DER } \\
=\frac{\text { Total Liabilitas }}{\text { Ekuitas }} \times 100 \%\end{array}$ \\
\hline $\begin{array}{l}\text { Current } \\
\text { Ratio }\end{array}$ & $\begin{array}{l}\text { CR } \\
=\frac{\text { Asset Lancar }}{\text { Liabilitas Lancar }} \times 100 \%\end{array}$ \\
\hline $\begin{array}{l}\text { Total } \\
\text { Asset } \\
\text { Turnover }\end{array}$ & $\begin{array}{l}\text { TAT } \\
=\frac{\text { Penjualan Neto }}{\text { Total Asset }} \times 100 \%\end{array}$ \\
\hline $\begin{array}{l}\text { Firm } \\
\text { Size }\end{array}$ & Firm Size $=$ Ln Total Asset \\
\hline
\end{tabular}

Dalam teknik analisis data regresi linier berganda dilakukan uji asumsi klasik dan linieritas.

\section{Uji Normalitas}

Uji Normalitas bertujuan untuk menguji apakah dalam model regresi, variabel pengganggu atau residual memliki distribusi normal. Seperti diketahui bahwa ujia $\mathrm{t}$ dan $\mathrm{f}$ mengasumsikan bahwa nilai residual mengikuti distribusi normal. Bila asumsi ini dilanggar maka uji statistik nonparametic dengan menggunakan Kolmogorov-Smirnov (K-S) (Ghozali, 2011: 160).

\section{Uji Multikolinearitas}

Menurut Ghozali (2011: 105) uji multikolonieritas bertujuan untuk menguji regresi yang baik seharusnya 
tidak terjadi korelasi di atntara variabel independen. Model ada tidaknya multikolonritas dalam model regresi dapat dilihat dari nilai tolerance dan lawannya variance inflation factor (VIF). Kedua ukuran ini menunjukan setiap variabel independen manakah yang dijelaskan oleh variabel independen menjadi dependen (terikat) dan regresi terhadap variabel independen lainnya. Tolerance mengukur variabilitas variabel independen yang terpilih yang tidak dijelaskan oleh variabel independen lainnya. Jadi nilai tolerance yang rendah sama dengan nilai VIF yang tinggi (Karena $\mathrm{VIF}=1 /$ tolerance). Nilai cutoff yang umum dipakai untuk menunjukan adanya multikolineritas adalah nilai tolerance $\leq$ 0,10 atau sama dengan nilai $\mathrm{VIF} \leq 10$.

\section{Uji Autokorelasi}

Menurut Ghozali (2011: 110) uji autokorelasi bertujuan untuk menguji apakah dalam model regresi linear ada korelasi antara kesalahan pengganggu pada periode $t$ dengan periode $t-1$ sebelumnya. Jika terjadi korelasi, maka dinamakan ada problem autokorelasi. Autokorelasi muncul karena observasi yang berurutan sepanjnag waktu berkaitan atau sama lainnya. Masalah ini timbul karena residual penelitian ini menggunakan Uji Durbin-Watson (DW test).
Tabel 3.4. Dasar Pengambilan

Keputusan Uji Autokorelasi

\begin{tabular}{|c|c|}
\hline Hipoteses nol & Jika \\
\hline $\begin{array}{c}\text { Tidak ada } \\
\text { autokorelasi } \\
\text { positif dan negative }\end{array}$ & $\mathrm{dU}<\mathrm{d}<(4-\mathrm{dU})$ \\
\hline $\begin{array}{c}\text { Terdapat } \\
\text { autokorelasi positif }\end{array}$ & $\mathrm{d}<\mathrm{dL}$ \\
\hline $\begin{array}{c}\text { Terdapat } \\
\text { autokorelasi negatif }\end{array}$ & $\mathrm{d}>(4-\mathrm{dL})$ \\
\hline
\end{tabular}

Sumber: Gujarati (2009: 469)

\section{Uji Heteroskedastisitas}

Uji Heteroskedatisitas bertujuan untuk menguji apakah dalam model regresi terjadi ketidaksamaan variance dari residual satu pengamatan ke pengamatan yang lain. Jika variance dari residual satu pengamatan ke pengamatan yang lain tetap disebut homokedastisitas, dan jika berbeda disebut heteroskedastisitas. Model regresi yang baik adalah homokedastisitas, atau tidak terjadi heteroskedastisitas. Uji ini dilakukan dengan meregresikan variabel bebas terhadap nilai absolute residualnya. Apabila tingkat probabilitas signifikansi itu $\alpha 5 \%$, maka dapat dikatakan mengandung heteroskedastisitas.

\section{Uji Linieritas}

Uji linearitas bertujuan untuk mengetahui apakah dua variabel mempunyai hubungan yang linear atau 
tidak secara signifikan. Uji ini biasanya digunakan sebagai prasyarat dalam analisis kolerasi atau regresi linear. Pengujian pada SPSS dengan menggunakan Test for linearity dengan taraf signifikan 0,05. Dua variabel dikatakan mempunyai hubungan yang linear bila signifikan kurang dari 0,05.

\section{ANALISIS DAN PEMBAHASAN}

\section{Hasil Penelitian}

Data dalam penelitian ini adalah data sekunder yang diperoleh dari data laporan keuangan publikasi tahunan pada Perusahaan Mining yang Terdaftar di BEI Tahun 2013-2018. Terdapat 25 Perusahaan yang telah mempublikasikan laporan keuangan secara lengkap selama periode 2013-2018. Sehingga diperoleh data observasi sebanyak 150 data untuk masing-masing variabel. Sebanyak 10 data dari masing-masing variabel harus dieleminasi karena termasuk data outlier yang dikhawatirkan menggangu hasil penelitian sehingga data yang digunakan hanya 140 data untuk masing-masing variabel. Berikut hasil analisis statistik deskriptif dari data penelitian yang disajikan dalam tabel 2

\section{Tabel 2. Statistik Deskriptif}

Descriptive Statistics

\begin{tabular}{|l|r|r|r|r|r|}
\hline & \multicolumn{1}{|c|}{$N$} & Minimum & Maximum & Mean & Std. Deviation \\
\hline CR & 140 & 16.91 & 691.36 & 180.0270 & 120.83045 \\
DER & 140 & 10.84 & 3405.56 & 145.0865 & 304.78207 \\
TAT & 140 & .24 & 1852.16 & 89.2072 & 206.38595 \\
FS & 140 & 25.64 & 32.27 & 29.2945 & 1.60505 \\
ROE & 140 & -282.98 & 77.32 & 4.9751 & 31.02620 \\
Valid N (listwise) & 140 & & & & \\
\hline
\end{tabular}

Tabel 2 menunjukkan Variabel Current Ratio (CR) memiliki nilai ratarata sebesar 180,03\%. Hal tersebut menunjukkan bahwa rata-rata perusahaan Mining yang terdaftar di BEI memiliki aset lancar 1,80 kali lebih banyak dari kewajiban lancarnya selama periode 2013-2018.

Variabel Debt to Equity Ratio (DER) memiliki nilai rata-rata sebesar 145,09\%. Hal tersebut menunjukkan bahwa rata-rata perusahaan Mining yang terdaftar di BEI memiliki total liabilitas 1,45 kali lebih banyak dari total ekuitasnya selama periode 2013-2018.

Variabel Total Asset Turnover (TAT) memiliki nilai rata-rata sebesar $89,21 \%$. Hal tersebut menunjukkan bahwa rata-rata perusahaan Mining yang terdaftar di BEI berhasil memperoleh pendapatan penjualan sebanyak 0,89 kali dari total aktivanya setiap tahun selama periode 2013-2018.

Variabel Firm Size (FS) memiliki nilai rata-rata sebesar 29,29. Hal tersebut menunjukkan bahwa rata-rata perusahaan 
Mining yang terdaftar di BEI memiliki ukuran perusahan sebesar Rp5.253.943.200 (anti Ln 29,29) selama periode 2013-2018.

Variabel Return on Equity (ROE) memiliki nilai rata-rata sebesar $4,96 \%$. Hal tersebut menunjukkan bahwa ratarata perusahaan Mining yang terdaftar di BEI berhasil memperoleh laba sebanyak $4,96 \%$ dari total ekuitasnya setiap tahun selama periode 2013-2018.

\section{Analisis}

Uji Asumsi Klasik berupa uji normalitas menunjukkan test distribution normal pada Asymmp.Sig.(2.tailled) sebesar 0,61 $>$ 0,05. Demikian pula hasil uji autokorelasi menggunakan uji Durbin Watson, diperoleh bahwa nilai $\mathrm{dU}<\mathrm{dW}<$ $(4-\mathrm{dU})(1,7678<1,969<2,2322)$ sehingga disimpulkan tidak terdapat gejala autokorelasi. Demikian pula hasil pengujian multikolinieritas, menunjukkan nilai tolerance untuk semua variabel lebih besar dari 0.10 dan nilai VIF untuk semua variabel juga berada dibawah 10 sehingga disimpulkan tidak terdapat gejala multikolinieritas antar variabel. Uji Heteroskedastisitas berdasarkan hasil uji Glejser, diperoleh nilai signifikansi pada masing-masing variabel independent terhadap nilai absolut dari residual model regresi lebih besar dari 0,05, sehingga disimpulkan tidak terdapat gejala heteroskedastisitas. Demikian pula uji linieritas terpenuhi.

\section{Uji T (Uji Pengaruh Parsial)}

Tabel 3.Uji T

\begin{tabular}{|c|c|c|c|c|c|c|}
\hline \multirow[b]{2}{*}{ Mode } & & \multicolumn{2}{|c|}{ Unstandarcized Coefficientis } & \multirow{2}{*}{$\begin{array}{c}\begin{array}{c}\text { Standardized } \\
\text { Coefficients }\end{array} \\
\text { Beta }\end{array}$} & \multirow[b]{2}{*}{1} & \multirow[b]{2}{*}{ Sig. } \\
\hline & & $B$ & Std. Error & & & \\
\hline \multirow[t]{5}{*}{1} & (Conslant) & -50.688 & 28.485 & & -1.779 & .077 \\
\hline & $\mathrm{CR}$ & -011 & .013 & .043 & .870 & .386 \\
\hline & DER & -083 & .005 & .818 & -16.580 & .000 \\
\hline & TAT & .024 & .008 & .161 & 3.231 & .002 \\
\hline & FS & 2.306 & .964 & .119 & 2.393 & .018 \\
\hline
\end{tabular}

a. Dependent Variable: ROE

Berdasarkan hasil analisis regresi linier berganda diperoleh persamaan regresi sebagai berikut:

$\mathrm{ROE}=-50.688-0.011 \mathrm{CR}-0.083$ $\mathrm{DER}+0.024 \mathrm{TAT}+2.306 \mathrm{FS}+\mathrm{e}$

a) Nilai konstanta sebesar 50.688 dengan nilai negatif. Hal ini menunjukkan jika variabel Current Ratio (CR), Debt to Equity Ratio (DER), Total Asset Turnover (TAT) dan Firm Size (FS) sama dengan nol maka besarnya Return on Equity (ROE) adalah negative atau perusahaan mengalami kerugian.

b) Besarnya nilai koefisien Current Ratio (CR) sebesar 0.011 dengan nilai negatif. Hal ini berarti bahwa setiap terjadi peningkatan Current Ratio (CR) maka Return on Equity 
(ROE) akan menurun dengan asumsi variabel yang lain konstan. Nilai signifikansi Current Ratio (CR) terhadap Return on Equity (ROE) pada uji T $0.386>0.05$, bermakna bahwa Current Ratio (CR) berpengaruh tidak signifikan terhadap Return on Equity (ROE)

c) Besarnya nilai koefisien Debt to Equity Ratio (DER) sebesar 0.083 dengan nilai negatif. Hal ini berarti bahwa setiap terjadi peningkatan Debt to Equity Ratio (DER) maka Return on Equity (ROE) akan menurun dengan asumsi variabel yang lain konstan. Nilai signifikansi Debt to Equity Ratio (DER) terhadap Return on Equity (ROE) pada uji T $0.000<$ 0.05, bermakna bahwa Debt to Equity Ratio (DER) berpengaruh negatif dan signifikan terhadap Return on Equity (ROE

d) Besarnya nilai koefisien Total Asset Turnover (TAT) sebesar 0.024 dengan nilai positif. Hal ini berarti bahwa setiap terjadi peningkatan Total Asset Turnover (TAT) maka Return on Equity (ROE) akan meningkat sebesar dengan asumsi variabel yang lain konstan. Nilai signifikansi Total
Asset Turnover (TAT) terhadap Return on Equity (ROE) pada uji T $0.002<0.05$, bermakna bahwa Total Asset Turnover (TAT) berpengaruh positif dan signifikan terhadap Return on Equity (ROE)

e) Besarnya nilai koefisien Firm Size (FS) sebesar 2.306 dengan nilai positif. Hal ini berarti bahwa setiap terjadi peningkatan Firm Size (FS) maka Return on Equity (ROE) akan meningkat dengan asumsi variabel yang lain konstan. Nilai signifikansi Firm Size (FS) terhadap Return on Equity (ROE) pada uji $\mathrm{T} 0.018<0.05$, bermakna bahwa Firm Size (FS) berpengaruh positif dan signifikan terhadap Return on Equity (ROE)

\section{Pembahasan}

\section{Pengaruh Current Ratio (CR) terhadap Return on Equity (ROE)}

Hasil pengujian menunjukkan bahwa Current Ratio (CR) berpengaruh tidak signifikan terhadap Return on Equity (ROE) pada Perusahaan Mining yang Terdaftar di BEI Tahun 2013-2018 yang bermakna bahwa peningkatan maupun penurunan Current Ratio (CR) belum tentu berdampak pada peningkatan maupun penurunan Return on Equity (ROE). Temuan ini tidak mendukung hipotesis bahwa Current Ratio (CR) 
berpengaruh signifikan terhadap Return on Equity (ROE).

Secara teori Current Ratio mampu menekan Return on Equity karena likuiditas yang terlalu besar adalah bentuk lemahnya manajemen dalam memanfaatkan aset yang menganggur sehingga menurunkan kesempatan perusahaan memanfaatkan asetnya untuk mendapatkan laba yang lebih besar.

2. Pengaruh Debt to Equity Ratio (DER) terhadap Return on Equity (ROE)

Hasil pengujian menunjukkan bahwa Debt to Equity Ratio (DER) berpengaruh negatif dan signifikan terhadap Return on Equity (ROE) pada Perusahaan Mining yang Terdaftar di BEI Tahun 2013-2018 yang bermakna bahwa peningkatan Debt to Equity Ratio (DER) akan menyebabkan penurunan Return on Equity (ROE). Sehingga Hipotesis kedua yang menyatakan bahwa Debt to Equity Ratio (DER) berpengaruh signifikan terhadap Return on Equity (ROE) diterima.

Tinggi rendahnya Debt to Equity Ratio (DER) akan mempengaruhi tingkat pencapian Return on Equity (ROE) perusahaan. Jika biaya yang ditimbulkan oleh pinjaman (cost of debt) lebih kecil daripada biaya modal sendiri (cost of equity), maka sumber dana yang berasal dari pinjaman atau hutang akan lebih efektif dalam menghasilkan laba (meningkatkan Return on Equity) dan demikian sebaliknya.

\section{Pengaruh Total Asset Turnover (TAT) terhadap Return on Equity (ROE)}

Hasil pengujian menunjukkan bahwa Total Asset Turnover (TAT) berpengaruh positif dan signifikan terhadap Return on Equity (ROE) pada Perusahaan Mining yang Terdaftar di BEI Tahun 2013-2018 yang bermakna bahwa peningkatan Total Asset Turnover (TAT) akan menyebabkan peningkatan Return on Equity (ROE). Sehingga Hipotesis ketiga yang menyatakan bahwa Total Asset Turnover (TAT) berpengaruh signifikan terhadap Return on Equity (ROE) diterima. Hal ini bermakna bahwa semakin besar Total Asset Turnover (TAT) akan semakin baik karena berarti semakin efisien seluruh aktiva yang digunakan untuk menunjang kegiatan penjualan dan menambahkan jumlah laba yang diperoleh oleh perusahaan.

\section{Pengaruh Firm Size (FS) terhadap}

\section{Return on Equity (ROE)}

Hasil pengujian menunjukkan bahwa Firm Size (FS) berpengaruh positif dan signifikan terhadap Return on Equity (ROE) pada Perusahaan Mining yang Terdaftar di BEI Tahun 2013-2018 yang 
bermakna bahwa peningkatan Firm Size (FS) akan menyebabkan peningkatan Return on Equity (ROE). Temuan ini mendukung Hipotesis keempat yang menyatakan bahwa Firm Size (FS) berpengaruh signifikan terhadap Return on Equity (ROE).

Ukuran perusahaan menunjukkan besar kecilnya suatu perusahaan. Sebuah perusahaan yang skalanya besar dan sahamnya tersebar luas memiliki kekuatan tersendiri dalam menghadapi masalah bisnis dan kemampuan perusahaan untuk menghasilkan laba lebih tinggi, karena usaha tersebut didukung oleh aset yang besar sehingga kendala perusahaan yang berhubungan dengan aset dapat diatasi.

\section{KESIMPULAN}

\section{Kesimpulan}

Berdasarkan hasil analisis dan pembahasan maka disimpulkan bahwa: pertama, Current Ratio (CR) berpengaruh tidak signifikan terhadap Return on Equity (ROE). Kedua Debt to Equity Ratio (DER) berpengaruh negatif dan signifikan terhadap Return on Equity (ROE). Ketiga, Total Asset Turnover (TAT) berpengaruh positif dan signifikan terhadap Return on Equity (ROE). Keempat Firm Size (FS) berpengaruh positif dan signifikan terhadap Return on Equity (ROE) dan kelima CR, DER, TAT,
FS secara simultan berpengaruh signifikan terhadap ROE.

\section{Saran}

Berdasarkan kesimpulan dapat disarankan bahwa: peneliti lanjutan diharapkan menggunakan variabel fundamental lainnya yang berpengaruh signifikan terhadap Return on Equity (ROE).

\section{DAFTAR PUSTAKA}

Belkaoui, Ahmed Riahi. 2011. Teori Akuntansi. Edisi 5. Jakarta: Salemba Empat.

Brigham F. Eugene dan Houston, Joel. 2010. Dasar-Dasar Manajemen Keuangan: Assetials Of Financial Management. Jakarta: Salemba Empat.

Fahmi, Irham. 2013. Analisis Laporan Keuangan. Bandung: Alfabeta.

Ghozali, Imam. 2011. Aplikasi Analisis Multivariate Dengan Program IBM SPSS 19. Edisi Kelima. Semarang: Universitas Diponegoro.

Gujarati, Damodar N. 2009. Basic Econometric 5th Edition. McGraw Hill: New York.

Hanafi, Mahduh dan Abdul Halim. 2012. Analisis Laporan Keuangan. Yogyakarta: (UPP) STIM YKPN.

Harahap, Sofyan Syafri. 2009. Analisis Kritis Atas Laporan Keuangan. Jakarta: Raja Grafindo Persada.

Hery. 2016. Analisis Laporan Keuangan. Jakarta: Grasindo. 
Home, James C. Van dan Machowiecz, John M. 2012. Fundamental of Financial Management. 13th Edition. United Kingdom: Pearson Education.

Ismi, Nurul. 2016. Pengaruh Debt to Equity Ratio dan Firm Size terhadap Return on Equity pada CV Dwikora Usaha Mandiri Periode 2011-2014. Journal Bisma Universitas Pendidikan Ganesha Jurusan Manajemen Volume 4.

Kasmir. 2013. Analisis Laporan Keuangan. Rajawali Pers: Jakarta.

Rudianto. 2013. Akuntansi Manajemen Informasi untuk Pengambilan
Keputusan Strategis. Jakarta: Erlangga.

Sawir, Agnes. 2009. Analisa Kinerja Keuangan dan Perencanaan Keuangan Perusahaan. Jakarta: PT Gramedia Pustaka Utama.

Sutrisno. 2012. Manajemen Keuangan: Teori, Konsep dan Aplikasi. Yogyakarta: Ekonisia.

Yulsiati, Henny. 2016. Pengaruh Debt to Assets Ratio (DAR), Debt to Equity Ratio (DER) dan Net Profit Margin (NPM) Terhadap Return On Equity Perusahaan Property dan Real Estate yang Terdaftar di Bursa Efek Indonesia Tahun 2010-2013. Jurnal Akuntanika 1 (2). Politeknik Negeri Sriwijaya. 